Egyptian Journal of Aquatic Biology \& Fisheries

Zoology Department, Faculty of Science,

Ain Shams University, Cairo, Egypt.

ISSN $1110-6131$

Vol. 25(6): 397 - 410 (2021)

www.ejabf.journals.ekb.eg

\title{
Reproductive Biology of Charybdis hellerii in Lasongko and Kendari Bays, Southeast Sulawesi, Indonesia
}

\author{
Abdul Hamid $^{* 1}$, Syamsul Kamri ${ }^{1}$, Muslim Tadjuddah ${ }^{1}$, Yusli Wardiatno ${ }^{2,3.4}$ \\ 1-Department of Aquatic Resources Management, Faculty of Fisheries and Marine Sciences, \\ Halu Oleo University, Kampus Hijau Bumi Tridharma Andounohu, Kendari 93232, Indonesia. \\ 2-Department of Aquatic Resources Management, Faculty of Fisheries and Marine Sciences, IPB \\ University, Kampus IPB Darmaga, Bogor 16680, Indonesia. \\ 3-Environmental Research Center, IPB University, Kampus IPB Darmaga, Bogor 16680, West \\ Java, Indonesia. \\ 4-Center for Coastal and Marine Resources Studies, IPB University, Kampus IPB Baranangsiang, \\ Bogor 16143, West Java, Indonesia.
}

*Corresponding author: abdhamid_lamun@yahoo.com

\begin{tabular}{l} 
ARTICLE INFO \\
Article History: \\
Received: May 17, 2021 \\
Accepted: Oct. 19, 2021 \\
Online: Dec. 29, 2021 \\
\hline Keywords: \\
Crustaceans, \\
Gonad development, \\
Sex ratio, \\
Sexual maturity, \\
Spawning season
\end{tabular}

ARTICLE INFO

Article History:

Accepted: Oct. 19, 2021

Online: Dec. 29, 2021

Keywords:

Crustaceans,

Gonad development,

Sexual maturity,

Spawning season

\section{ABSTRACT}

Limited Data have been found on the reproductive biology of Charybdis hellerii (A. Milne-Edwards, 1867) in Indonesia. To fill this gap, the current study aimed to analyze various aspects of the reproductive biology of $C$. helleri, male and female, in Lasongko and Kendari Bays. Using traps, samples of crab species were monthly collected (from MarchNovember 2019) with the help of blue swimming crab fishermen. Results showed that the total sex ratio of $C$. hellerii in Lasongko and Kendari Bays were 1: 0.48 and 1: 0.57 , respectively. However, the temporally sex ratio of the crabs varied. In Lasongko Bay, male gonads of $C$. hellerii were majorly immature, while those of the females and ovigerous females were mature. Meanwhile, in Kendari Bay, all three types were predominantly immature, and they were all temporally varied. The first sizes sexual maturity of the male and female $C$. hellerii in Lasongko Bay were $60.04 \mathrm{mmCW}$ and 53.12 mmCW, respectively, while those of Kendari Bay were $60.23 \mathrm{~mm} \mathrm{CW}$ and $53.24 \mathrm{mmCW}$, respectively. The spawning season of this crab species tends to occur throughout the year. Therefore, the data obtained in this study can be used for the management of $C$. hellerii in Lasongko and Kendari Bays and Southeast Sulawesi waters.

INTRODUCTION

The Charybdis hellerii species was first restricted to inhibit the Western Indo Pacific region (Wee \&Ng, 1995; Spiridonov, 1999; Cabi, 2020); however, since these crabs are globally invasive (Watanabe $\boldsymbol{e t}$ al., 2015), they are widely distributed in various continents, including: Asia, Africa, America, Australia and Europe (Cabi, 2020). These crabs have been detected in the intertidal zone at a depth of $51 \mathrm{~m}$ (Stephenson $\boldsymbol{e t}$ al., 1957; Lamaitre, 1995; Wee \& Ng, 1995; Cabi, 2020). Furthermore, their habitat 
contains mudflats substrate (Stephenson et al., 1957; Wee \& Ng, 1995; Spiridonov, 1999), rock fragments, coral reefs, rock piles (Lamaitre, 1995; Wee \& Ng, 1995; Cabi 2020), seagrass beds and algae, in addition to mangrove roots in the sand (Spiridonov 1999; Dineen et al., 2001; Ferry et al., 2017), ).

Most studies on $C$. hellerii are generally associated with invasive species; namely, Lemaitre (1995), Dineen et al. (2001), Mantelatto and Garcia (2001), Ozcan et al. (2010), Bolanos et al. (2012), Sant'Anna et al. (2012), Watanabe et al. (2015), Ferry et al. (2017), Evans et al. (2018) and Searles et al. (2019). Furthermore, research on the reproductive biology of $C$. hellerii as an invasive species was carried out in the studies of Mantelatto and Garcia (2001), Bolanos et al. (2012), Sant'Anna et al. (2012) and Ferry et al. (2017). Nevertheless, research on the reproductive biology of $C$. hellerii in the Western Indo Pacific region is still limited, and the only found study was conducted on the Persian Gulf coast (Bahremand $\boldsymbol{e t}$ al., 2018). Notably, no research has been conducted on the Indonesian waters.

Information on the aspects of reproductive biology is essential for crab management policies, such as determining the fishing season, size and phase that can be caught (Kamrani et al., 2010; Ikhwanuddin et al., 2012; Zairion et al., 2015; Hamid et al., 2016a, b, 2017; Hamid \& Wardiatno, 2018a) as well as its stock assessment (Abdelhak et al., 2020). Data on the aspects of reproductive biology include sex ratio, gonad development, ovigerous female, first size sexual maturity and spawning season (Kamrani et al., 2010; Ikhwanuddin et al., 2012; Hamid et al., 2015, 2016a,b, 2017; Zairion et al., 2015; Tureli \& Yesilyurt, 2017; Hamid \& Wardiatno, 2018a).

The waters of Lasongko and Kendari Bays are potential fishing grounds in Southeast Sulawesi for the blue swimming crab, Portunus pelagicus (Hamid \& Wardiatno, 2018b; Hamid et al., 2020). All $C$. hellerii found in this study are bycatches of blue swimming crab fisheries, which use traps and gillnets. However, the aspects of their reproductive biology are not known till now. This study was focused to determine aspects of the reproductive biology of male and female of $C$. hellerii in Lasongko and Kendari Bays. The studied aspects included sex ratio, gonad development, first size sexual maturity and spawning season.

\section{MATERIALS AND METHODS}

This study was conducted in Lasongko and Kendari Bays, Southeast Sulawesi at eleven locations of the blue swimming crab fishermen sites (Fig.1). It was conducted from March till November 2019, and crab sampling was performed by blue swimming crab fishermen through the use of traps. 


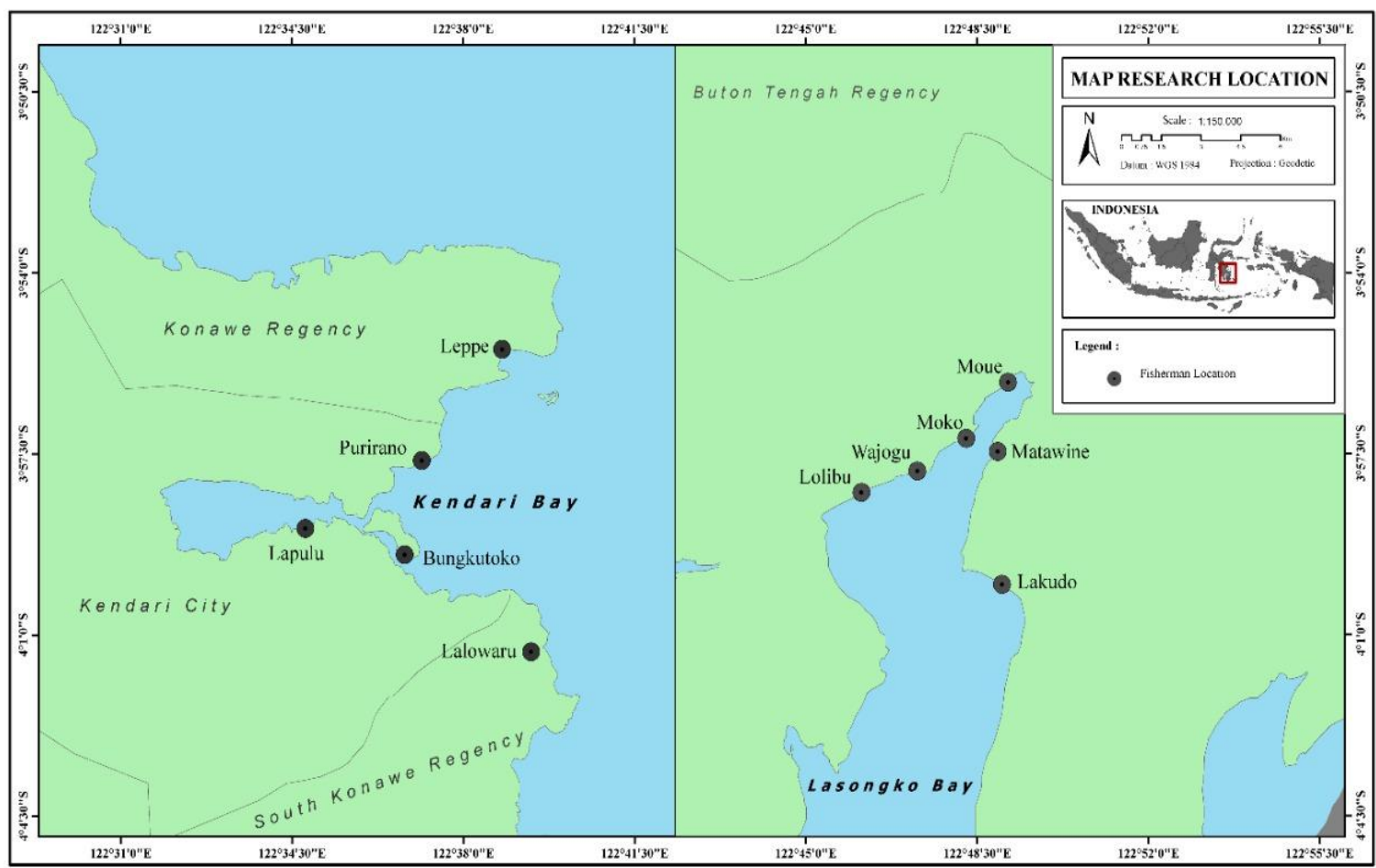

Fig. 1. Map of research and locations of the landing of blue swimming crab fisherman (black circles) in Lasongko and Kendari Bays, Southeast Sulawesi, Indonesia Modified by (Hamid \& Kamri, 2019)

A total number of 600 individuals of $C$. hellerii, with males and females in addition to ovigerous females, were subjected to analysis in the present study. Crab carapace width was measured using digital calipers (Vernier Caliper 0-150 mm x 0.05) with an accuracy of $0.05 \mathrm{~mm}$. The carapace of each crab was opened to detect their gonad development; for $C$. hellerii female, four stages were determined. Those stages were identified based on the morphological changes, the color and the distribution of ovaries occupying hepatic (Kamrani et al., 2010; Ikhwanuddin et al., 2012; Hamid et al., 2016a). On the other hand, three stages were detected for the gonad development of $C$. hellerii male, based on the morphological changes, the color, and the distribution of testes and vas deferens (de Lestang et al., 2003; Hamid et al., 2016a).

The sex ratio of $C$. hellerii was analyzed with respect to the sampling period and the total number of crabs at each study location. Furthermore, sex ratio was determined by dividing the number of females by the number of males, using the following equation: sex ratio : $\frac{\sum \text { Female }}{\sum \text { Male }}$ (Hamid \& Wardiatno, 2018a). Statistical test $(\chi 2)$, using the equation of $\mathrm{p}=0.05$ (Steel \& Torrie, 1980), was performed to state the balance of the ratio of males to females (sex ratio $1: 1$ ).

The progress of gonadal development of $C$. hellerii was descriptively analyzed in accordance to sex, sampling period and changes in the color of the ovigerous female 
eggs. Spawning season is remarkably dependent on the presence of ovigerous female of C. hellerii (Karmani et al., 2010; Hamid et al., 2015, 2016a, 2018).

The carapace width of the first size sexual maturity was analyzed using an explorer curve of 12.0 and determined using the successive logistic model equation as follows: $\mathrm{P}=$ 1 $(1+\exp [-\mathrm{r}(\mathrm{L}-\mathrm{Lm})])$ (King, 2017); where $\mathrm{P}$ is the progress of the crab's gonad maturity; $\mathrm{r}$ is the slope of the curve; $\mathrm{L}$ is mean carapace witdh $(\mathrm{mm})$, and $\mathrm{Lm}$ is carapace witdh at $50 \%$ sexual maturity $(\mathrm{mm})$. The width of the class used for analyzing the frequency distribution of carapace width was $3 \mathrm{~mm}$.

\section{RESULTS}

\section{Carapace Width and Sex Ratio}

The carapace widths of males $C$. hellerii in the Lasongko Bay ranged between 42.26 and $78.89 \mathrm{~mm}$, while those of the females ranged between 42.78 and $68.65 \mathrm{~mm}$. Furthermore, the carapace widths of the Kendari Bay ranged between 36.08 and 89.84 $\mathrm{mm}$ and $36.81 \& 66.70 \mathrm{~mm}$, for males and females, respectively. On the other hand, the carapace widths of the ovigerous females of $C$. hellerii in Lasongko Bay ranged between 45.28 and $63.88 \mathrm{~mm}$, and in the Kendari Bay, the carapace widths ranged from 38.34 $65.01 \mathrm{~mm}$.

The sex ratio of $C$. hellerii determined in this study varied; the total of which was 1: 0.48 in the Lasongko Bay, while in the Kendari Bay, the ratio was 1: 0.57. Both figures were significantly different $(\mathrm{p}<0.05)$ from a sex ratio of $1: 1$ because they were unbalanced. The sex ratio of $C$. hellerii from each sampling in the Lasongko Bay ranged from 1:0.27 to 1:0.94, while that of the Kendari Bay ranged from 1: 0.17 to 1: 0.91 (Table $1)$.

Table 1. The monthly number and sex ratio of $C$. hellerii in Lasongko and Kendari Bays, Southeast Sulawesi, Indonesia

\begin{tabular}{lcccccc}
\hline \multirow{2}{*}{$\begin{array}{c}\text { Sampling } \\
\text { time }\end{array}$} & \multicolumn{3}{c}{ Lasongko Bay } & \multicolumn{3}{c}{ Kendari Bay } \\
\cline { 2 - 7 } & Male & Female & $\begin{array}{c}\text { Sex ratio } \\
(\mathbf{M}: \mathbf{F})\end{array}$ & Male & Female & $\begin{array}{c}\text { Sex ratio } \\
(\mathbf{M}: \mathbf{F})\end{array}$ \\
\hline March & - & - & & 26 & 5 & $1: 0.19$ \\
April & 0 & 0 & & 34 & 29 & $1: 0.85$ \\
May & 26 & 19 & $1: 0.70$ & 46 & 28 & $1: 0.61$ \\
June & 23 & 3 & $1: 0.14$ & 11 & 3 & $1: 0.27$ \\
July & 33 & 9 & $1: 0.27$ & 6 & 1 & $1: 0.17$ \\
August & 13 & 8 & $1: 0.62$ & 20 & 5 & $1: 0.25$ \\
September & 34 & 32 & $1: 0.94$ & 0 & 1 & - \\
October & 44 & 15 & $1: 0.34$ & 22 & 20 & $1: 0.91$ \\
November & 26 & 9 & $1: 0.35$ & 36 & 22 & $1: 0.61$ \\
\hline Total & 190 & 95 & $1: 0.48^{*}$ & 201 & 114 & $1: 0.57 *$ \\
\hline \multicolumn{2}{c}{ Note: *significantly different $(\mathrm{p}<0.05)$} & $0=$ not found - = no sampling was done &
\end{tabular}




\section{Gonad Development}

The gonad development of $C$. hellerii males in the Lasongko Bay was mostly immature, while the majority of the females and ovigerous crabs had mature gonads. In the Kendari Bay, all three (males, females \& ovigerous females) were dominated by immature gonads (Table 2). The gonad developments (between sampling periods) of males and females of $C$. hellerii in Lasongko and Kendari Bays were different (Fig. 2).

Table 2. Gonad development conditions of male, female, and ovigerous female of $C$. hellerii in Lasongko and Kendari Bays, Southeast Sulawesi, Indonesia

\begin{tabular}{lcccc}
\hline Sex & Undeveloped (\%) & Immature (\%) & Mature (\%) & Total (ind.) \\
\hline Male & 18.13 & Lasongko Bay & \\
Female & 13.83 & 71.50 & 10.36 & 193 \\
Ovigerous & 3.39 & 34.04 & 52.13 & 94 \\
\hline \multicolumn{5}{c}{ Kendari Bay } \\
Male & 23.00 & 48.50 & 57.63 & 59 \\
Female & 11.54 & 48.08 & 28.50 & 200 \\
Ovigerous & 4.55 & 65.91 & 29.38 & 104 \\
\hline
\end{tabular}

The gonad development of $C$. hellerii males in Lasongko and Kendari Bays (between sampling periods) was mostly of stages I and II (immature). Furthermore, the highest proportion of stage III (mature) crabs in Lasongko Bay was found in June, while that of Kendari Bay occurred in June (Fig. 2). The gonad development of $C$. hellerii females in Lasongko Bay (between sampling periods) was mostly dominated in stage III and IV (mature), whereas that of the Kendari Bay tended to balance between stages I and II (immature) and stages III and IV (mature).

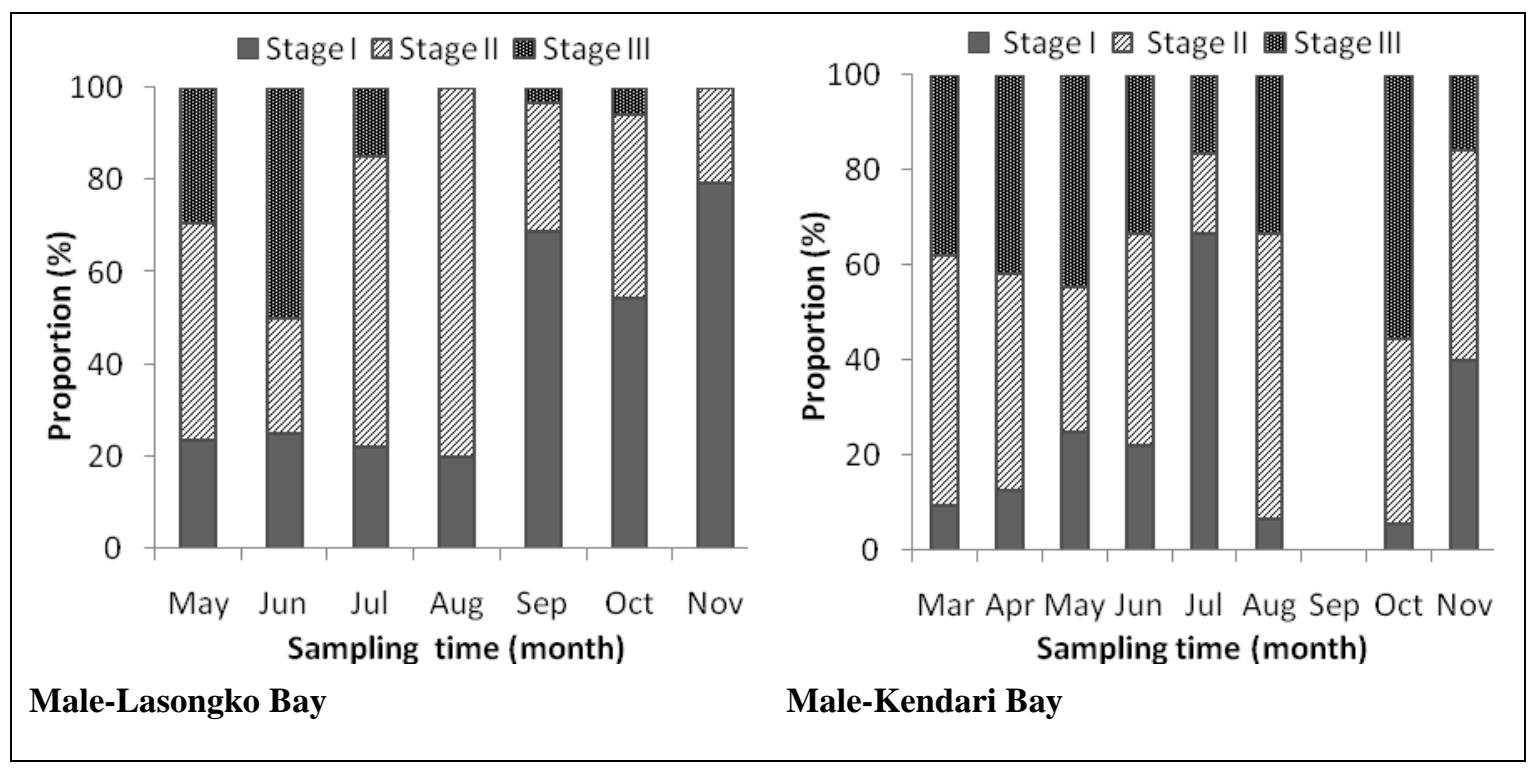




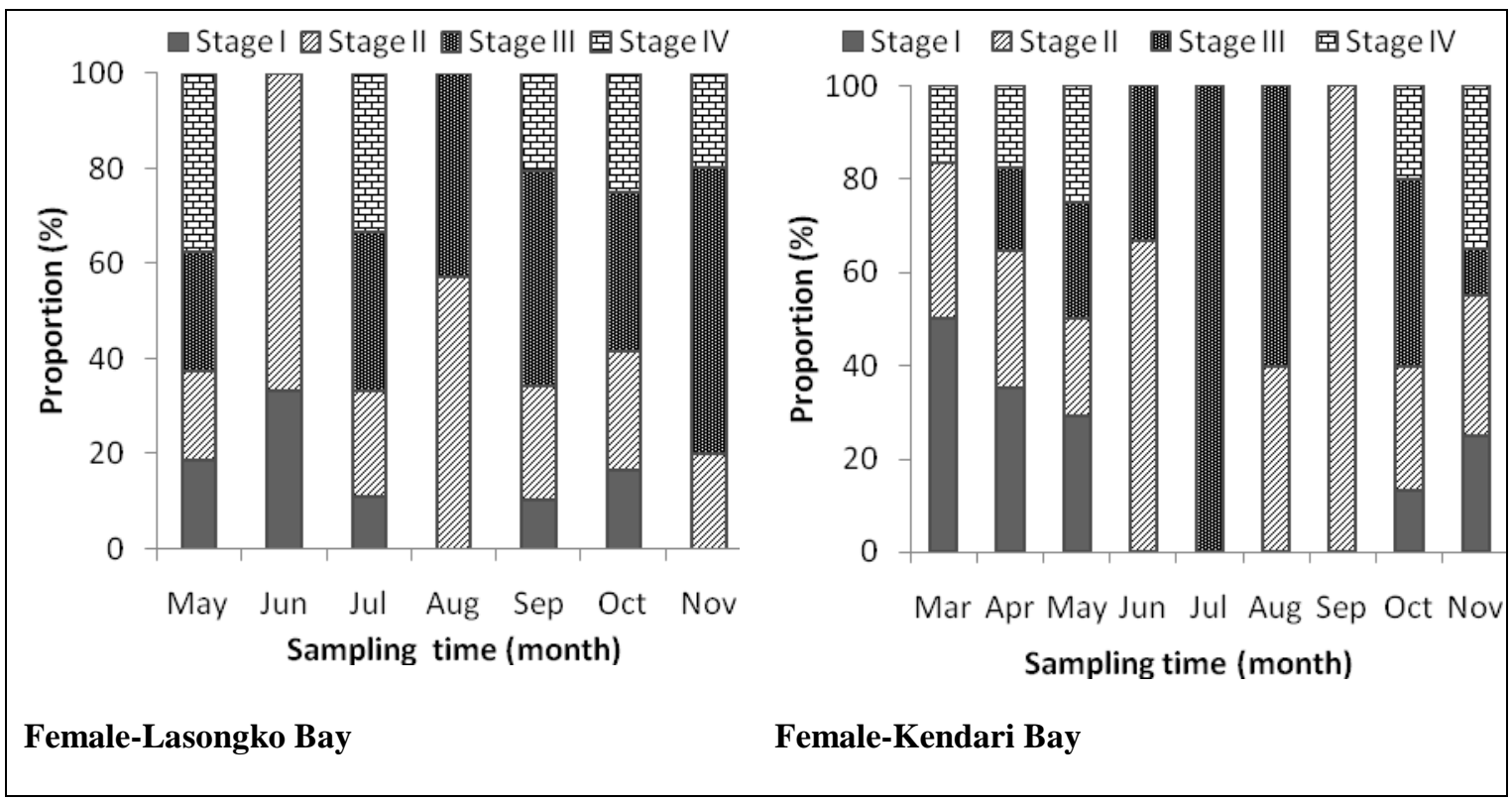

Fig. 2. The proportion of gonads stage of male and female of $C$. hellerii in each sampling time in Lasongko and Kendari Bays, Southeast Sulawesi, Indonesia

The gonad development of yellow female ovigerous of $C$. hellerii in Lasongko and Kendari Bays ranged from stages I to IV, while the other three egg colors in Lasongko Bay were found in stages III and IV. Consequently, the gonad development of the orange colored ovigerous female of $C$. hellerii in Kendari Bay consisted of stages II, III and IV, while those in brown and dark gray consisted of stages I, II and IV (Fig. 3).

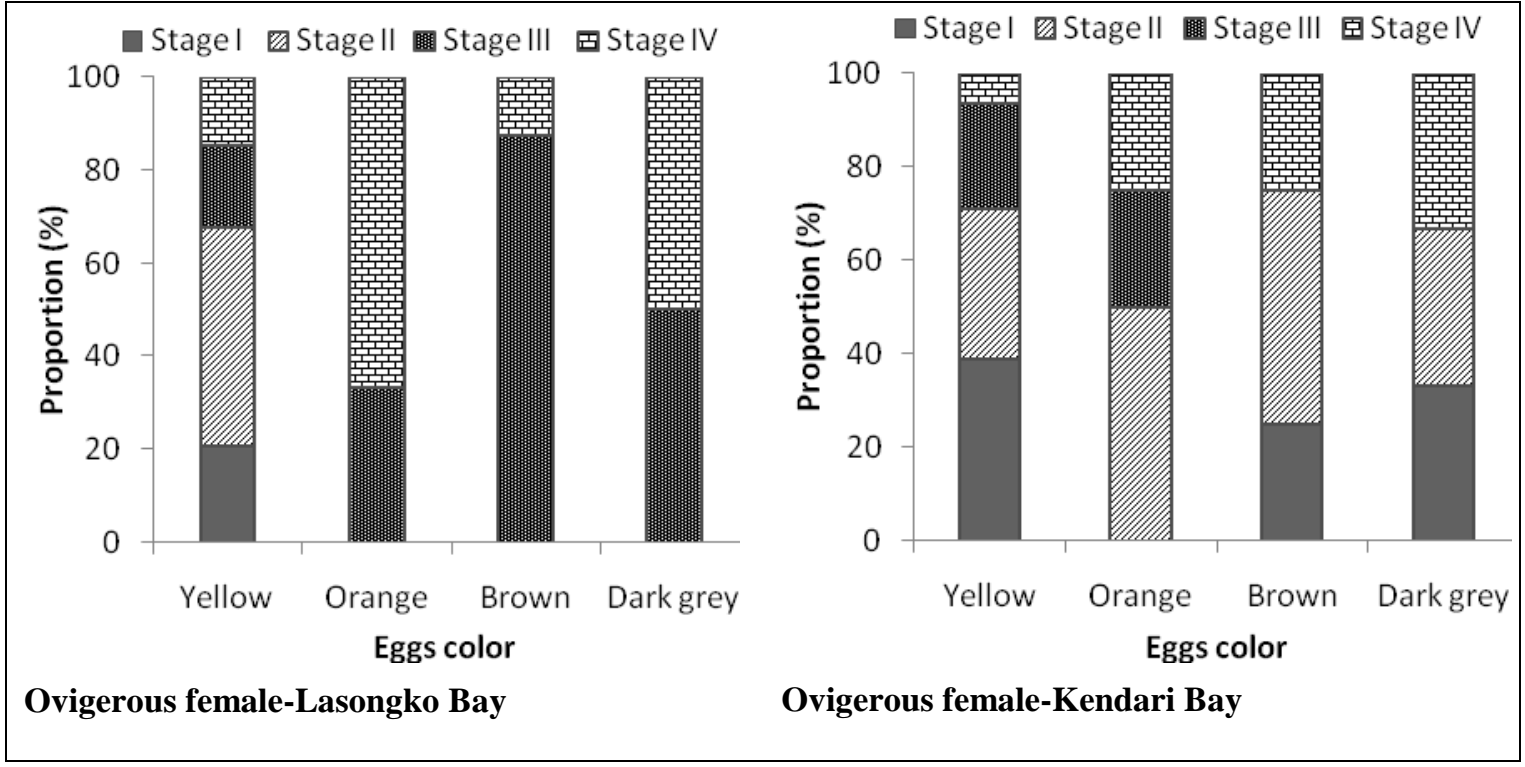

Fig. 3. The proportional gonad stages of female ovigerous $C$. hellerii based on egg color in Lasongko and Kendari Bays, Southeast Sulawesi, Indonesia 


\section{Ovigerous Female and Spawning Season}

The number of ovigerous females of $C$. hellerii in Lasongko Bay was 59 (62.11\%), while their number in Kendari Bay was 44 (38.60\%). Ovigerous females of $C$. hellerii were found almost every month. However in July, none was found in Kendari Bay. In addition in April, female and ovigerous female crabs were not found in Lasongko Bay (Table 3 \& Fig. 4).

Table 3. Number and proportion of ovigerous female (OF) to female of $C$. hellerii in each sampling time in Lasongko and Kendari Bays, Southeast Sulawesi, Indonesia

\begin{tabular}{lcccccc}
\hline \multirow{2}{*}{$\begin{array}{l}\text { Sampling } \\
\text { time }\end{array}$} & $\begin{array}{c}\text { Female } \\
\text { number } \\
\text { (ind.) }\end{array}$ & $\begin{array}{c}\text { OF } \\
\text { number } \\
\text { (ind.) }\end{array}$ & $\begin{array}{c}\text { OF } \\
\text { Proportion } \\
(\%)\end{array}$ & $\begin{array}{c}\text { Female } \\
\text { number } \\
\text { (ind.) }\end{array}$ & $\begin{array}{c}\text { OF } \\
\text { number } \\
\text { (ind.) }\end{array}$ & $\begin{array}{c}\text { OF } \\
\text { Proportion } \\
\text { (\%) }\end{array}$ \\
\hline March & - & - & - & 5 & 3 & 60.00 \\
April & 0 & 0 & 0 & 29 & 7 & 24.14 \\
May & 19 & 14 & 71.43 & 28 & 19 & 67.86 \\
June & 3 & 2 & 66.67 & 3 & 2 & 66.67 \\
July & 9 & 4 & 44.44 & 1 & 0 & 0 \\
August & 8 & 7 & 87.50 & 5 & 2 & 40.00 \\
September & 32 & 21 & 65.63 & 1 & 1 & 100.00 \\
October & 15 & 10 & 66.67 & 20 & 3 & 15.00 \\
November & 9 & 1 & 11.11 & 22 & 7 & 31.82 \\
\hline Total & 95 & 59 & 62.11 & 114 & 44 & 38.60 \\
\hline Note:0= not found & $-=$ no sampling was done & & &
\end{tabular}

The spawning season of $C$. hellerii in Lasongko and Kendari Bays due to the presence of ovigerous females tends to exist around the year. However, the peak spawning season of $C$. hellerii in Lasongko Bay occurs during May and September, while that of Kendari Bay only occurs in May (Fig. 4).

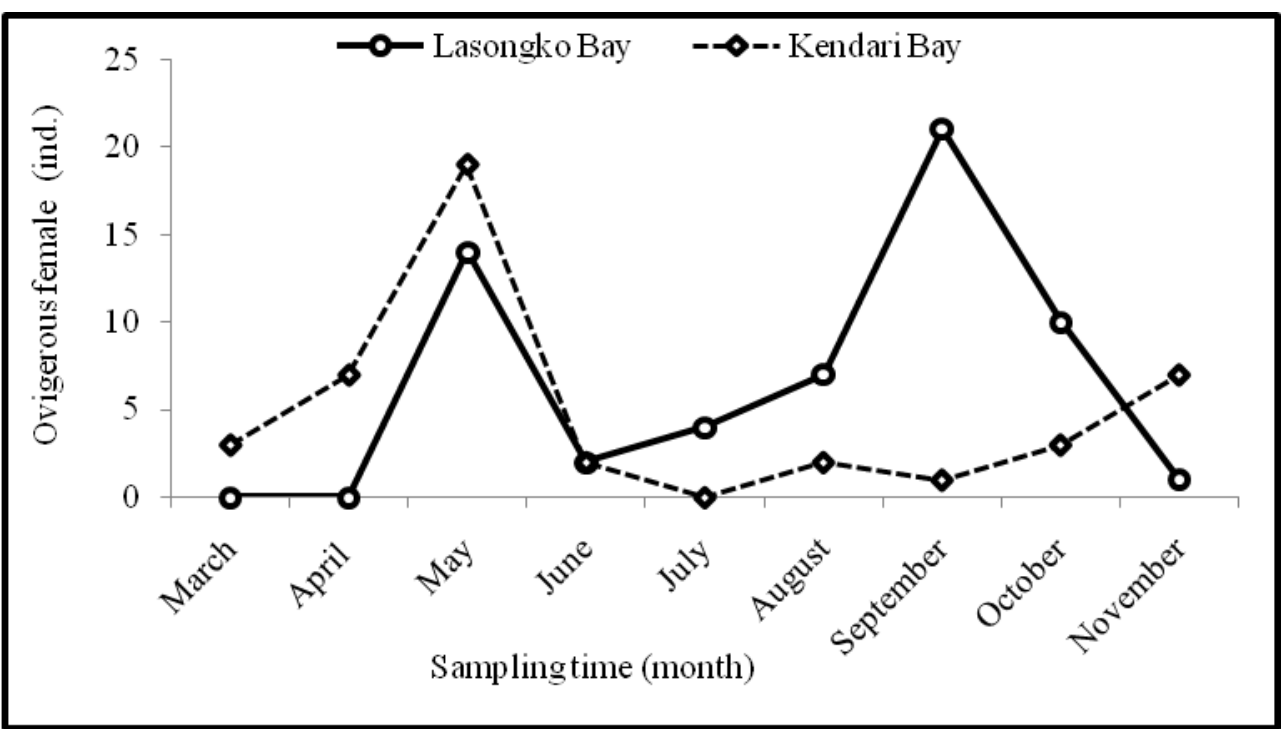

Fig. 4. The presence of $C$. hellerii ovigerous female in each month in Lasongko and Kendari Bays, Southeast Sulawesi, Indonesia 


\section{First size sexual maturity}

The first size at $50 \%$ of sexual maturity $(\mathrm{CW} 50 \%)$ in $C$. hellerii male in Lasongko Bay was $60.04 \mathrm{~mm} \mathrm{CW}$, while in the female, it was $53.12 \mathrm{~mm} \mathrm{CW}$. On the other hand, in Kendari Bay, the sizes were $60.23 \mathrm{~mm} \mathrm{CW}$ and $53.24 \mathrm{~mm} \mathrm{CW}$, respectively (Table 4 \& Fig. 5).

Table 4. Initial sizes of sexual and gonad maturity of male and female in Lasongko and

Kendari Bays Southeast Sulawesi, Indonesia

\begin{tabular}{lcc}
\hline \multirow{2}{*}{ Sex } & \multicolumn{2}{c}{ First size sexual maturity-CW50\% $(\mathbf{m m})$} \\
\cline { 2 - 3 } & Lasongko Bay & Kendari Bay \\
\hline Male & 60.04 & 60.23 \\
Female & 53.12 & 53.24 \\
\hline & CW-size minimum gonad maturity $(\mathbf{m m})$ \\
Male & 42.26 & 37.98 \\
Female & 36.81 & 45.43 \\
\hline
\end{tabular}

The smallest identified carapace size of $C$. hellerii ovigerous females in Lasongko Bay was $45.28 \mathrm{mmCW}$, while that of Kendari Bay was $38.34 \mathrm{mmCW}$. Furthermore, the smallest carapace width of $C$. hellerii mature gonad is shown in Table (4).

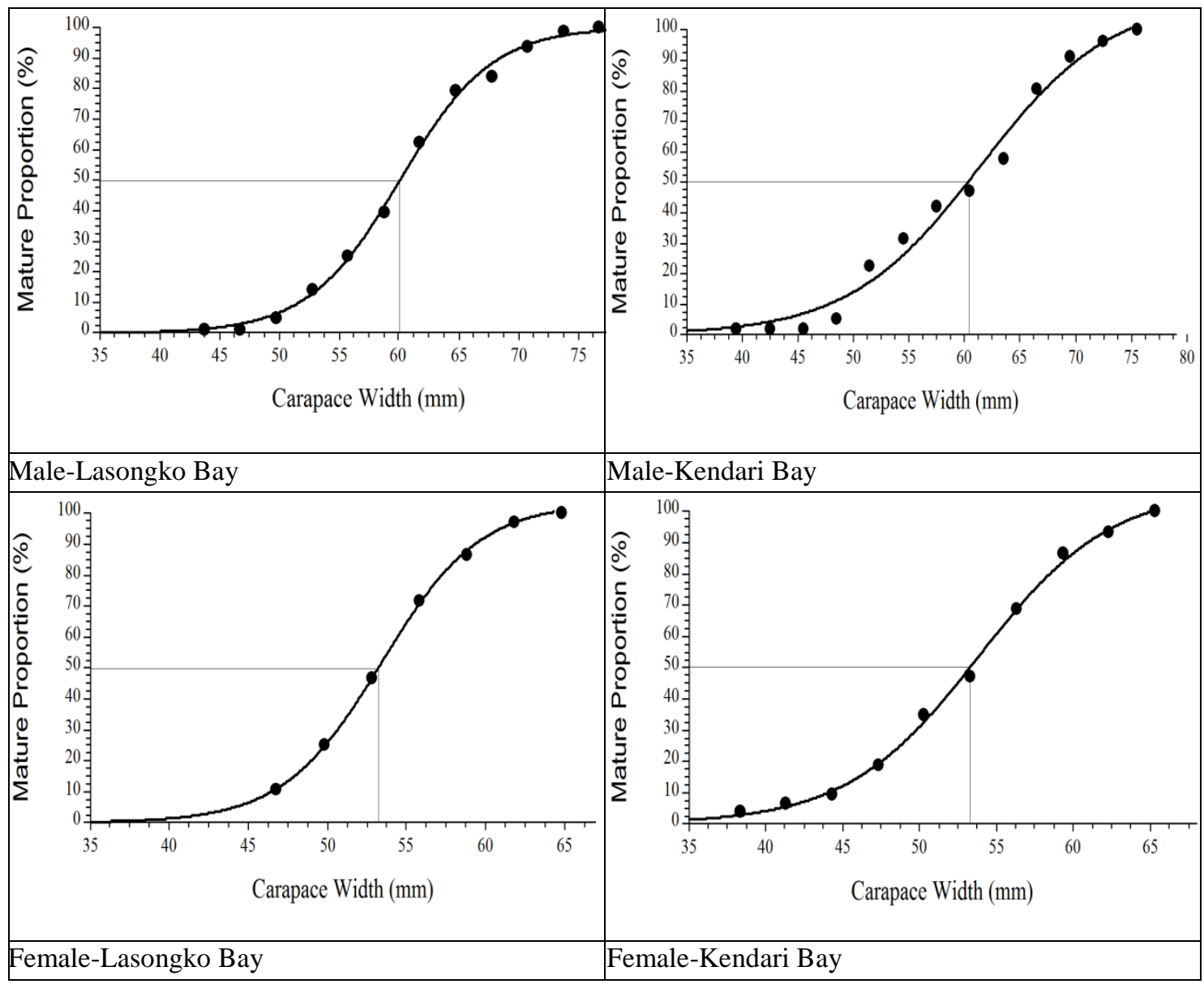

Fig.5. Logistic curve estimating first size at $50 \%$ sexual maturity of $C$. hellerii male and female in Lasongko and Kendari Bays, Southeast Sulawesi, Indonesia 


\section{DISCUSSION}

The total sex ratio of $C$. hellerii in Lasongko Bay was smaller than that of Kendari Bay (Table 1). Furthermore, the detected sex ratio of $C$. hellerii in some waters varied, and the females were more than the males (Table 5). The sex ratio of $C$. hellerii obtained in this study are greater than those of Sant'Anna et al. (2012), Bolanos et al. (2012) and Ferry et al. (2017), whereas it is smaller than the sex ratio determined in the study of Bahremand $\boldsymbol{e t}$ al. (2018) as presented in Table (5) In comparison, the obtained sex ratio of $C$. hellerii is lower than those detected with respect to $C$. natator (Sumpton, 1998; Vidhya, 2016) and $C$. bimaculata (Doi et al., 2008), but higher than the sex ratio of $C$. feriata (Nieves et al., 2015) and C. anisodon (Hamid \& Wardiatno, 2018a, Table 5).

Table 5. Sex ratio and spawning season of $C$. hellerii and other species at several water locations

\begin{tabular}{|c|c|c|c|c|}
\hline Location & Species & $\begin{array}{l}\text { Sex } \\
\text { ratio }\end{array}$ & $\begin{array}{l}\text { Spawning } \\
\text { season }\end{array}$ & Source \\
\hline São Vicente, Brazil & C. hellerii & 1: 0.32 & Year-round & Sant'Anna et al. ( 2012) \\
\hline Caribia sea,Venezuela & C. hellerii & $1: 0.46$ & Year-round & Bolanos et al. (2012) \\
\hline Martinique, France & C. hellerii & $1: 0.42$ & - & Ferry et al. (2017) \\
\hline Persian Gulf, Iran & C. hellerii & $1: 0.74$ & Year-round & Bahremand et al. (2018) \\
\hline Lasongko Bay, Indonesia & C. hellerii & $1: 0.48$ & Year-round & \multirow{2}{*}{ This study (2021) } \\
\hline Kendari Bay, Indonesia & C. hellerii & $1: 0.57$ & Year-round & \\
\hline Moreton Bay, Queensland & C. natator & $1: 0.55$ & Year-round & Sumpton (1998) \\
\hline Mannar Bay, India & C. natator & $1: 0.62$ & Year-round & Vidhya (2016) \\
\hline Tokyo Bay, Japan & C. bimaculata & 1: 2.07 & $\begin{array}{l}\text { Not year- } \\
\text { round }\end{array}$ & Doi et al. (2008) \\
\hline Northeastern New Zealand & C. japonica & 1: 0.65 & $\begin{array}{l}\text { Not year- } \\
\text { round }\end{array}$ & Wong (2013) \\
\hline Karnataka, India & C. feriata & 1: 1 & Year-round & Dineshbabu (2011) \\
\hline San Miguel Bay, Philippines & C. feriata & 1: 0.50 & Year-round & Nieves et al.(2015) \\
\hline Lasongko Bay, Indonesia & C. anisodon & $1: 0.38$ & Year-round & $\begin{array}{l}\text { Hamid and Wardiatno } \\
\text { (2018a) }\end{array}$ \\
\hline
\end{tabular}

The sex ratio of $C$. hellerii in this study varied with the sampling periods. This is identical to the results obtained in the Caribbean Sea, Venezuela (Bolanos et al., 2012), on the Persian Gulf coast, Iran (Bahremand $\boldsymbol{e t}$ al., 2018), and also in crabs such as $C$. anisodon (Hamid \& Wardiatno, 2018a). Additionally, the present finding is similar to that detected with respect to $C$. natator in India (Kannathasan \& Rajendran, 2011). The variation in the sex ratio may be attributed to the tendency of crabs to spawn and forage at Portunidea, the differences in sampling procedures and vartions in seasons (Kannathasan \& Rajendran 2011; Hamid et al., 2016a; Hamid \& Wardiatno, 2018a). The differences in longevity and growth rates can also cause the aforementioned phenomenon (Doi et al., 2008). 
The pattern of gonad development in the C. hellerii of Lasongko and Kendari Bays was identified from the sex, sampling period, and the change in eggs' color of ovigerous females which tend to be different. The gonad development of $C$. hellerii male in Lasongko and Kendari Bays was dominated by immature gonads, however the percentage did not match. Consequently, the gonad development in Lasongko Bay was higher than that in Kendari Bay (Table 2). The gonad development of female and ovigerous female of $C$. hellerii in Lasongko Bay was dominated by mature gonads, while in Kendari Bay, immature gonads were dominant (Table 2).

The gonad development of $C$. hellerii male in Lasongko and Kendari Bays, depending on the sampling period, was generally dominated by immature gonads, while the proportions between the two were different. The proportion of immature male of $C$. hellerii in Lasongko Bay ranged from 71.00-100\%, while in Kendari Bay, it ranged from 56.00- 84.00\%. In addition, the proportion of male crabs in Lasongko Bay with matured gonads was lower than that detected in Kendari Bay (Fig. 2). The gonad development of C. hellerii female in Lasongko Bay, according to the sampling period, was dominated by mature gonads, and ranged from 58.33- 80.00\%. While, that of Kendari Bay was dominated by immature gonads, with proportions ranging from 55.00-100\% (Table 2). The gonad development of male and female of $C$. hellerii were variant, which is similar to the results found in the study of Bahremand et al. (2018) on the Persian Gulf coast, Iran. Moreover, the current result coincides with those of de Lestang et al. (2003), Ikhwanuddin et al. (2012) and Hamid et al. (2016a) who deduced the same finding in their works on crabs; namely, P. pelagicus and that of Wong (2013) conducted on $C$. japonica.

The proportion of $C$. hellerii ovigerous female in Lasongko and Kendari Bays with immature gonads were low, recording values of $3.39 \%$ and $4.55 \%$ (Table 2). This indicates that most ovigerous females of $C$. hellerii found in this study had embryonic and gonadal developments though they did not occur simultaneously. The embryonic development of ovigerous female of $C$. hellerii is characterized by an egg color change; from yellow to dark gray during the incubation period (Hamid et al., 2015, 2016c). Consequently, the proportion of (gonad development) ovigerous female of $C$. hallerii in Kendari Bay in stage IV increased when the color of the crab's eggs changed from yellow to dark gray (Fig. 3).

The development of gonads and embryos recorded in ovigerous females of $C$. hellerii indicates that these crabs spawned partially. Sperm that was not used by ovigerous female of $C$. hellerii was stored in the seminal receptacle to support subsequent gonad development (Dineen et al., 2001; Sant'Anna et al., 2012). It is worthy to mention that, this is a strategy used to increase the success of larval production (Dineen et al., 2001; Sant'Anna et al., 2012; Hamid et al., 2015).

The spawning season of $C$. hellerii in Lasongko and Kendari Bays occurs throughout the year, however that of ovigerous females in Lasongko Bayare was not 
found in July. Furthermore, in July, the mature gonads of the females (stage III, Fig. 2) could be found. In addition, 7 ovigerous females of $C$. hellerii in Kendari Bay were found in July 2018 (Hamid, data not published). In previous studies (; Bolanos et al., 2012; Sant'Anna et al., 2012; Bahremand et al., 2018), it was reported that $C$. hellerii spawned throughout the year (Table 5).

The initial sizes of sexual maturity (CW50\%) in male and female of C. hellerii in Lasongko and Kendari Bays were relatively similar, and both showed that male sizes were larger than those of the females (Table $4 \&$ Fig. 5). The size of CW 50\% female of C. hellerii in this study relatively concurs with those detected on the Persian Gulf coast, Iran, which was $54.55 \mathrm{~mm} \mathrm{CW}$ (Bahremand et al., 2018). The smallest recorded size (sexual maturity) of $C$. hellerii ovigerous female is smaller than those of Stephenson $\boldsymbol{e t}$ al. (1957) in Australia which were $47 \mathrm{~mm}$ and matured in the laboratory at $77 \mathrm{~mm} \mathrm{CW}$ in 12 months (Dineen et al., 2001).

The smallest size of $C$. hellerii ovigerous female found in Lasongko Bay was bigger than that found in Kendari Bay. In comparison, it is bigger than the sizes detected on the Persian Gulf coast, Iran, which was $38 \mathrm{~mm}$ CW (Bahremand et al., 2018). Therefore, the smallest size of mature gonads in the C. hellerii of Lasongko Bay was greater than that found in Kendari Bay because the female crabs in Kendari Bay were larger than those found in Lasongko Bay (Table 4).

\section{CONCLUSION}

The total sex ratio in Lasongko and Kendari Bays were 1:0.48 and 1:0.57, respectively, and the temporally sex ratio of $C$. hellerii varied. The gonad development of C. hellerii male in Lasongko Bay were mostly immature, while females and ovigerous females were dominated by mature gonads. Meanwhile, in Kendari Bay, all the three sexes tend to be dominated by immature gonads, and the gonad development of male and female of $C$. hellerii temporarily varied. The first sizes of sexual maturity in the male and female of $C$. hellerii in Lasongko Bay were $60.04 \mathrm{mmCW}$ and $53.12 \mathrm{~mm} \mathrm{CW}$, respectively, while those of Kendari Bay were $60.23 \mathrm{mmCW}$ and $53.24 \mathrm{mmCW}$, respectively. The spawning season of C.hellerii tends to occur throughout the year. Consequently, the data obtained in this study can be used for fishing management, specifically for determining the size of crabs that can be caught and the fishing season of C.hellerii in Lasongko and Kendari Bays and the Southeast Sulawesi waters.

\section{REFERENCES}

Abdelhak, E.M; Madkour, F.F; El Ganainy,A.A; Abu El-Regal, M.A. and Ahmed, M.I. (2020). Reproductive biology of Siganus rivulatus (Forsskal, 1775) in the Red Sea, Suez Canal and the Mediterranean Sea, Egypt. Egypt. J. Aquat. Biol. Fish., 24(6): 117-134. 
Bahremand, M.; Safaie, M. and Momeni, M. (2018). Reproductive biology of swimming crab, Charybdis hellerii (A. Milne-Edwards, 1867) in coastal waters of the Persian Gulf (Hormuzgan province). J. Aquat. Ecol., 7(4): 40-49. (in Persian).

Bolanos, J.A.; Baeza, J.A.; Hernandez, J.E.; Lira, C. and Lopez, R. (2012). Population dynamics and reproductive output of the non-indigenous crab Charybdis hellerii in the south-eastern Caribbean Sea. J. M. Biol. Assoc. United Kingdom, 92(3): 469-474. DOI: 10.1017/S002531541100052X.

Cabi. (2020). Charybdis hellerii. https://www.cabi.org/isc/datasheet/109135\#tosummary of invasiveness. Accessed 28 February 2020.

de Lestang, S.; Hall, N.G. and Potter, I.C. (2003). Reproductive biology of the blue swimmer crab (Portunus pelagicus, Decapoda: Portunidae) in five bodies of water on the west coast of Australia. Fish. Bull., 101:745-757.

Dineen, J.F.; Clark, P.F.; Hines, A.H.; Reed, S.A. and Walton, H.P. (2001). Life history, larval description, and natural history of Charybdis hellerii (decapoda, brachyura, portunidae), an invasive crab in the Western Atlantic. J. Crustacean Biol., 21(3): 774-805.

Doi,W., Yokota, M.; Strussmann, C.A.and Watanabe, S. (2008). Growth and reproduction of the portunid crab Charybdis bimaculata (Decapoda: Brachyura) in Tokyo Bay. J. Crustacean Biol., 28(4): 641-651. https://doi.org/10. 1651/072964.1.

Evans, N.; Zill, J. and Paulay, G. (2018). Sixty-seven years on the lam: new records of a non-native swimming crab, Charybdis hellerii (A. Milne-Edwards, 1867) (Decapoda: Brachyura: Portunidae), in the Hawaiian Islands. J. Crustacean Biol., 38(5): 641-645. https://doi.org/10.1093/jcbiol/ruy059.

Ferry, R.; Buske, Y.; Poupin, J. and Smith-Ravin, J. (2017). First record of the invasive swimming crab Charybdis hellerii (A. Milne Edwards, 1867) (Crustacea, Portunidae) off Martinique, French Lesser Antilles. BioInvasions Rec., 6(3):239247. https://doi.org/10.3391/bir.2017.6.3.09.

Fowler, A.E. (2011). Biological and ecological attributes of a population of the invasive Asian paddle crab, Charybdis japonica, in northeastern New Zealand (Ph.D thesis), The University of Auckland. 159pp.

Hamid, A. and Wardiatno, Y. (2018a). Biological aspects of Charybdis anisodon (De Haan, 1850) in Lasongko Bay, Central Buton, Southeast Sulawesi, Indonesia. Biodiversitas, 19(5): 1755-1762. DOI: 10.13057/biodiv/d190523.

Hamid, A. and Wardiatno, Y. (2018b). Diversity of decapod crustaceans in Lasongko Bay, South-east Sulawesi,Indonesia. Biodiv. J., 9 (3): 303-311. DOI: 10.31396/ Biodiv.Jour.2018.9.3.303.311.

Hamid, A.and Kamri, S. (2019). Bycatches of blue swimming crab fishing in Lasongko and Kendari Bay Southeast Sulawesi. Mar. Fish., 10(2): 215-224. https://doi.org /10.29244/jmf.v10.i2.30855. (in Indonesian). 
Hamid, A.; Wardiatno, Y.; Lumban Batu, D.T.F. and Riani, E. (2015). Fecundity and gonad maturity stages of ovigerous female blue swimming crab (Portunus pelagicus) in Lasongko Bay, Southeast Sulawesi. Bawal, 7(1): 43-50. https://dx. doi.org/10.15578/bawal.7.1.2015.43-50 (in Indonesian).

Hamid, A.; Lumban Batu, D.T.F.; Riani, E. and Wardiatno, Y. (2016a). Reproductive biology of blue swimming crab (Portunus pelagicus Linnaeus, 1758) in Lasongko Bay, Southeast Sulawesi-Indonesia. AACL Bioflux, 9(5): 1053-1066.

Hamid, A.; Wardiatno, Y.; Lumban Batu, D.T.F. and Riani, E. (2016b). Distribution, body size, and eggs of ovigerous swimming crab (Portunus pelagicus Linnaeus 1758) at various habitats in Lasongko Bay, Central Buton, Indonesia. Int. J. Aquat. Biol., 4 (2): 115-124. DOI: 10.7508/ijab.2016.02.006.

Hamid, A.; Wardiatno, Y. and Irawati, N. (2019). Biological aspects of genus Thalamita Latreille, 1829 (Decapoda: Portunidae) in Lasongko Bay, Southeast Sulawesi, Indonesia. AACL Bioflux, 12(4): 1335-1348.

Hamid, A.; Kamri, S.; Irawati, N. and Wardiatno, Y. (2020). Community structure of crustacean bycatch of blue swimming crab (Portunus pelagicus) fisheries in Kendari Bay, Southeast Sulawesi, Indonesia. AACL Bioflux, 13 (2): 694-704.

Ikhwanuddin, M.; Azra, M.; Siti-Aimuni, H. and Abol-Munafi, A.B. (2012). Fecundity, embryonic and ovarian development of blue swimming crab, Portunus pelagicus (Linnaeus, 1758) in coastal water of Johor, Malaysia. Pakistan J. Biol. Sci., 15:720-728. DOI: 10.3923/pjbs.2012.720.728.

Kamrani, E.; Sabili, A.N. and Yahyavi, M. (2010). Stock assessment and reproductive biology of the blue swimming crab, Portunus pelagicus in Bandar Abbas coastal waters, northern Persian Gulf. J. Persian Gulf (Mar. Sci.), 1(2): 11-22.

Kannathasan, A. and Rajendran, K. (2011). Sex ratio of the portunidae crab Charybdis natator (Herbst,1794) from Nagapattinam, southeast coast of Bay of Bengal, India. Elixir Bio-Tech., 40: 5388-5390.

Kebede, M.T.; Getahun, A and Lemma, B. (2018). Reproductive biology of commercially important fish species in Lake Langeno, Ethiopia. Asian Fish. Sci., 31(4): 319-339. https://doi.org/10.33997/j.afs.2018.31.04.006.

Lemaitre, R. (1995). Charybdis hellerii (Milne Edwards, 1867), a non-indigenous portunid crab (Cruastacea: Decapoa: Brachyura) discovered in the Indian River lagoon system of Florida. Proc. Biol. Soc.Washington, 108(4):643-648.

Mantelatto, L.M. and Garcia, R.B. (2001). Biological aspects of the non indigenous Portunid crab Charybdis hellerii in the Western Tropical South Atlantic. Bull. Mar. Sci., 68 (3): 469-477.

Nieves, P.M.; Olfindo, N.R. and Macale, A.M. (2015). Reproductive biology of christian crabs (Charybdis feriatus, Linnaeus, 1758) in San Miguel Bay, Philippines. Kuroshio Sci., 9 (1):13-16. 
Özcan, T., Kataan, T. and Irmak, E. (2010). An exotic crab, Charybdis hellerii (A. Milne-Edwards, 1867) along the Turkish Coasts. Biharean Biol., 4(1):1-5.

Sant'Anna, B.S., Watanabe, T.T.; Turra, A. and Zara, F.J. (2012). Relative abundance and population biology of the non-indigenous crab Charybdis hellerii (Crustacea: Brachyura: Portunidae) in a southwestern Atlantic estuary-bay complex. Aquat. Invasions, 7(3): 347-356.http://dx.doi.org/10.3391/ai.20127.3. 006.

Searles, A.R.; Gipson, E.E. and Cook, G.S. (2019). Notes on the discovery of an invasive marine decapod, Charybdis hellerii, in Mosquito Lagoon, Florida. Florida Sci., 82(1): 40-46.

Spiridonov, V.A. (1999). Results of the rumphius bio historical expedition to Ambon (1990). Part 8. Swimming crabs of Ambon (Crustacea: Decapoda: Portunidae). Zool. Meded. Leiden, 73: 63-97.

Steel, R.G.D. and Torrie, J.H. (1980). Principles and Procedure of Statistics: a Biometric Approach. McGraw-Hill Book Co., New York, 622 pp.

Stephenson, W., Hudson, J.J. and Campbell, B. (1957). The Australian portunids (Crustacea: Portunidae). II. The genus Charybdis. Australian J. Mar. Fresh. Res. 8: 491-507.

Sumpton, W. (1998). Biology of the rock crab Charybdis natator (Herbst) (Brachyura: Portunidae). Bull. Mar. Sci., 46 (2): 425-431.

Vidhya, V. (2016). Population biology and stock assessment of selected Portunus species of Gulf of Mannar (M.Sc thesis). Fisheries College and Research Institute Tamil Nadu Fisheries University. 79pp.

Watanabe, T.T., Zara, F.J.; Hattori, G.Y.; Turra, A. and Sant'Anna, B.S. (2015). Biological associations of color variation in the Indo-Pacific swimming crab Charybdis hellerii. Annals Brazil. Acad. Sci., 87(1): 219-232. https://dx.doi.org/ 10.1590/0001-37652015201.30388.

Wee, D.P.C. and Ng, P.K.L. (1995). Swimming crabs of the genera Charybdis De Haan, 1833, and Thalamita Latreille, 1829 (Crustacea: Decapoda: Brachyura: Portunidae) from peninsular Malaysia and Singapore. The Raffles Bul. Zool. 1:1128.

Wong, N.A.C.W. (2013). The reproductive biology, population genetics, and origin of invasion of the Asian paddle crab,Charybdis japonica, in north-eastern New Zealand (Ph.D thesis), The University of Auckland. 180pp.

Zairion; Wardiatno, Y. and Fahrudin, A. (2015). Sexual maturity, reproductive pattern, and spawning female population of the blue swimming crab, Portunus pelagicus (Brachyura: Portunidae) in East Lampung Coastal Waters, Indonesia. Indian J. Sci. Tech., 8(7): 596-607. DOI: 10.17485/ijts/201 /v8i7/69368. 